Piśmiennictwo zakonne $w$ dobie staropolskiej, red. Magdalena Kuran, Katarzyna KaczorScheitler i Michał Kuran, przy współpracy Dawida Szymczaka, Łódź 2013.

Michat Kuran ${ }^{1}$

Uniwersytet Łódzki

\title{
Hagiograficzny wizerunek świątobliwej wdowy Doroty Barzi - konstruowanie wzorców osobowych w kazaniu o. Adama Makowskiego Roczna i wieczna pamiątka
}

W twórczości jezuity Adama Makowskiego (ok. 1575-1657) biografistyka laudacyjna i kreowanie wzorców osobowych odgrywały znaczącą rolę. Pisarz i mówca znany był przede wszystkim jako autor popularnego w XVII wieku żywota mistyczki krakowskiej Barbary Lang Kwiat świątobliwego żywota $(1655)^{2}$. Napisał także kazanie towarzyszące złożeniu ślubów czystości przez pozostającą w stanie świeckim Zuzannę Amendowną (Wesele święte i wieczne szlachetnie urodzonej Panny [...] ku zbudowaniu pospolitemu, za dozwoleniem Starszych i Urzędu Duchownego do druku podane, Kraków 1628) oraz kazanie wygłoszone w pierwszą rocznicę śmierci wdowy po wojewodzie krakowskim Stanisławie Barzim, znanej dewotki krakowskiej, Doroty Barzi (ok. 1541-1613), Roczna i wieczna pamiątka. Obecnie Makowskiego kojarzymy najbardziej z kazaniem ku czci dominikanina, kaznodziei obozowego i potem królewskiego, o. Fabiana Birkowskiego (Obraz Wielebnego Ojca Fabiana Birkowskiego, Kraków 1636). Makowski napisał także modlitewniki zachęcające do udziału w nabożeństwach para-

\footnotetext{
${ }^{1}$ Michał Kuran studia polonistyczne ukończył w roku 1996 na Uniwersytecie Łódzkim. Od roku 1998 pracuje w Katedrze Literatury Staropolskiej i Nauk Pomocniczych tejże uczelni. Stopień doktora uzyskał w roku 2003, zaś doktora habilitowanego w 2013 roku. Od roku 2009 pełni funkcję wicedyrektora Instytutu Filologii Polskiej, należy do zespołu redakcyjnego „Czytania Literatury”.

Główne obszary zainteresowań badawczych to literatura polska XVII wieku. W szczególności literatura okolicznościowa (poezja i proza), edytorstwo tekstów dawnych, epika staropolska, zwłaszcza dorobek Samuela Twardowskiego i Marcina Paszkowskiego. Michał Kuran jest autorem książek Retoryka, historia i tradycja literacka w twórczości okolicznościowej Samuela Twardowskiego (Łódź 2008) oraz Marcin Paszkowski - poeta okolicznościowy i moralista z pierwszej połowy XVII wieku (Łódź 2012). Współredagował (z Janem Okoniem) m.in. tom Literatura staropolska w dydaktyce uniwersyteckiej (Łódź 2007), jak też (z Krystyną Płachcińska) tom okolicznościowy Miscellanea literackie i teatralne (od Kochanowskiego do Mrożka), cz. I-II (Łódź 2010) wydany z okazji 70-tych urodzin Profesora Jana Okonia. Wydał tomik Ksiąze Janusz Wiśniowiecki (1598-1636) w lubelskich kazaniach pogrzebowych (Lublin 2007, w serii Lubelska Biblioteka Staropolska). Publikował artykuły w „Terminusie”, „Baroku”, „Napisie”, „Pracach Polonistycznych”, „Acta Universitatis Lodziensis - Folia Litteraria Polonica”, „Acta Universitatis Lodziensis — Folia Librorum” i w „Akapicie” oraz w monograficznych tomach zbiorowych. Recenzje ogłaszał w „Ruchu Literackim”, „Pamiętniku Literackim” i „Studiach Źródłoznawczych”.

${ }^{2}$ Zob. K. Estreicher, Bibliografia polska, t. 22, Kraków 1908, s. 52-54.
} 
liturgicznych: Wzywanie do modlitwy codzinnej przy Ofierze Świętej (Kraków 1640), Postne nabożeństwo dla ludzi pobożnych krótko i prosto opisane (Kraków 1630). Znamy go też jako autora kazań okolicznościowych poświęconych zwycięstwu smoleńskiemu Władysława IV Wazy w roku $1634^{3}$.

Oracja ku czci Doroty Barzi stała się źródłem danych biograficznych, po które sięgano w opracowaniach przedstawiających jej życie i czyny. O znaczeniu tej wdowy w dobie staropolskiej świadczą dość obszerne biografie pozostawione w kompendiach Kaspra Niesieckiego (Herbarz polski) ${ }^{4}$ oraz Floriana Jaroszewicza (Matka świętych Polska) ${ }^{5}$. Również współczesne opracowania biograficzne uwzględniły tę postać. Poświęcono jej hasła w Polskim stowniku biograficznym ${ }^{6}$ oraz Encyklopedii katolickiej ${ }^{7}$. Jej biografię zamieścił także Jerzy Paszenda SJ w monografii kościoła św. Barbary w Krakowie ${ }^{8}$. Wprawdzie Zbigniew Kuchowicz 9 nie przedstawił dokonań Doroty Barzinej $\mathrm{w}$ charakterystykach znanych kobiet baroku, mimo to można zaryzykować stwierdzenie, że jej postawa i działania wpisały się trwale także we współczesną świadomość dziejów pobożności tamtej doby ${ }^{10}$.

Celu obecnej wypowiedzi nie stanowi podjęcie kolejnej próby rekonstrukcji biografii postaci, ale analiza wizerunku pochwalnego stworzonego przez o. Adama Makowskiego. Wizerunek ów wpisany został w formę oratorską. Autor respektuje reguły konstrukcji kazania rocznicowego. Konwencję wyzyskuje w celu postawienia zmarłej pomnika, jaki stworzyła sobie sama, żyjąc pobożnie, spełniając uczynki miłosierdzia i wspierając materialnie jezuitów oraz ubogich. Tytuł oracji zdaje się wskazywać na taki zamiar piszącego: Roczna i wieczna pamiatka [...] Doroty z Ojźrzakowa Barżynej [...] przy mszy żałobnej wystawiona. Literacki wizerunek wymaga oglądu w świetle konwencji pisarstwa hagiograficznego. Jest to konieczne tym bardziej, że Dorotę Barzi określano mianem świątobliwej, czyli bogobojnej, świętej ${ }^{11}$.

\footnotetext{
${ }^{3}$ Zob. Makowski Adam, [w:] Encyklopedia kościelna, wyd. ks. M. Nowodworski, t. 13, Warszawa 1880, s. 94; M. B., Makowski Adam, [w:] Podręczna encyklopedia kościelna, oprac. St. Gall i in., t. 25-26, Warszawa 1911, s. 174; L. Grzebień, Makowski Adam, [w:] Stownik polskich teologów katolickich, red. H. E. Wyczawski OFM, t. 3, Warszawa 1982, s. 39; B. Natoński, Makowski Adam, [w:] Polski stownik biograficzny, t. 19, Wrocław 1974, s. 234-235; Makowski Adam, [w:] Encyklopedia wiedzy o jezuitach na ziemiach Polski $i$ Litwy 1564-1995, oprac. L. Grzebień SJ przy współpracy zespołu jezuitów, Kraków 2004, s. 401.

${ }^{4}$ K. Niesiecki, Korona polska, t. 2, Lwów 1738, s. 268-270 (przedstawiona pod nazwiskiem panieńskim); tenże, Herbarz polski, wyd. J. N. Bobrowicz, t. 4, Lipsk 1839, s. 215-217.

${ }^{5}$ F. Jaroszewicz, Matka swiętych Polska albo żywoty swiętych błogostawionych, wielebnych, światobliwych, pobożnych Polaków i Polek..., Kraków 1767, s. 273-274.

${ }^{6}$ I. Kotowa, Barzina z Ojrzakowa Dorota, [w:] Polski stownik biograficzny, t. 1, Kraków 1935, s. 346.

${ }^{7}$ J. Bazydło, Barzi Dorota, [w:] Encyklopedia katolicka, t. 2, red. F. Gryglewicz, R. Łukaszyk, Z. Sułowski, Lublin 1976, kol. 92.

${ }^{8}$ J. Paszenda, Kościót św. Barbary w Krakowie z domem zakonnym księży jezuitów, Kraków-Wrocław 1985, Biblioteka Krakowska nr 125, s. 320-321.

${ }^{9}$ Z. Kuchowicz, Wizerunki niepospolitych niewiast staropolskich XVI-XVIII wieku, Łódź 1974; tenże, Żywoty niepospolitych kobiet polskiego baroku, Łódź 1989.

${ }^{10}$ Zob. też Hagiografia polska. Stownik bio-bibliograficzny, red. o. R. Gustaw OFM, t. 2, Poznań-Warszawa-Lublin 1971 (Aneks, s. 648).

${ }^{11}$ Zob. S. B. Linde, Stownik języka polskiego, t. 5, Lwów 1859, s. 516-517.
} 
O swoistości oracji decyduje także okazja, w związku z którą została ona napisana. Kazanie przygotowano w rocznicę śmierci krakowskiej dewotki ${ }^{12}$. Tak więc nie są silnie obecne w nim już wątki epicedialne, ich miejsce zajęły natomiast nawiązania do konwencji pisarstwa hagiograficznego.

\section{Z BIOGRAFII DOROTY BARZI}

Biografia Doroty Barzi (ok. 1541-1613) ze współczesnej perspektywy przedstawia się następująco: była córką Piotra Goryńskiego wojewody mazowieckiego i Agnieszki Sobockiej ${ }^{13}$. Wyszła za Kaspra Mińskiego (zm. 1564), wojskiego warszawskiego, z którym miała syna, Stanisława (ok. 1561-1607) ${ }^{14}$, podkanclerzego koronnego i poetę równie mocno jak matka zaangażowanego religijnie po stronie obozu kontrreformacyjnego, oraz córkę Annę, zmarłą w dzieciństwie. Po śmierci Mińskiego Dorota Goryńska poślubiła katolika - bliskiego współpracownika Stanisława Hozjusza - Stanisława Barziego, wojewodę krakowskiego, który zmarł wkrótce po objęciu urzędu w 1571 roku $^{15}$. Nie wiemy, czym zajmowała się Barzina od śmierci męża do roku 1580, nie wiemy też, kiedy dokonała się jej przemiana duchowa pod wpływem kazań Kaspra Czarnkowskiego oraz z inspiracji pierwszej protektorki jezuitów krakowskich, Zofii Mnichowskiej z Brzezin (zm. 1590) ${ }^{16}$. W jej zaangażowaniu zwracają uwagę obfite jałmużny składane na rzecz krakowskich jezuitów i kościół św. Barbary (m.in. sfinansowanie naprawy organów, coroczna wypłata 800 florenów na rzecz nowicjatu jezuickiego, ofiarowanie kamienicy ${ }^{17}$ ), jak też przede wszystkim prowadzenie dzieł charytatywnych i wychowawczych (troska o chorych i więźniów oraz sieroty). Wojewodzina krakowska opiekowała się pannami, które przygotowywała do życia konsekrowanego.

Dorota Barzi była pierwszą członkinią utworzonego przez Piotra Skargę Bractwa Miłosierdzia ${ }^{18}$. Według Makowskiego, zmarła przeżywszy 72 lata o godzinie 14 dnia 9 kwietnia 1613 roku $^{19}$ (lub 10 maja $)^{20}$. Została pochowana w kościele św. Barbary w Krakowie 25 czerwca 1613 roku w wystawionej dla siebie krypcie usytuowanej pod głównym ołtarzem po stronie północnej ${ }^{21}$. Barzinej dedykowali swe prace Jakub

\footnotetext{
${ }^{12}$ Zob. M. Skwara, Polskie drukowane oracje pogrzebowe XVII wieku. Bibliografia, Gdańsk 2009, s. 634.

${ }^{13}$ I. Kotowa, Barzina Dorota, [w:] Polski stownik biograficzny, t. 1, s. 346.

${ }^{14}$ S. Gruszecki, Miński Stanistaw, [w:] tamże, t. 21, Wrocław 1976, s. 320.

${ }^{15}$ St. Bodniak, Barzi Stanisław, [w:] tamże, t. 1, s. 345.

${ }^{16}$ J. Paszenda, $d z$. cyt., s. 321 i 329.

${ }^{17}$ Tamże, s. 69, 320-321.

${ }^{18}$ Zob. Ksiązka pamiątkowa Arcybractwa Miłosierdzia i Banku Pobożnego w Krakowie od roku 1584 do 1884 skreślona w roku jubileuszowym, Kraków 1884, s. 150.

${ }^{19}$ A. Makowski, Roczna i wieczna pamiątka Jaśnie Wielmożnej i Mitościwej Paniej Jej Mrośsi Prani Doroty z Ojźrzakowa Barżynej, wojewodzinej krakowskiej w Kościele Ś więtej, Barbary od Ojców Profesów Societatis Iesu, 10. dnia kwietnia wznowiona $i$ z katedry kaznodziejskiej przy mszej żałobnej wystawiona, Kraków 1614 , s. 42

${ }^{20}$ J. Paszenda, dz. cyt., s. 321.

${ }^{21}$ Tamże, s. 76.
} 
Wujek (Żywot Jezusa Chrystusa 1591), Piotr Skarga (Gospodarstwo duchowne 1606), Marcin Paszkowski (Dyjalog abo Rozmowa Grzesznego cztowieka z Anjoty 1612). Już jednak w roku 1581 anonimowy tłumacz-jezuita przypisał jej, jak też Elżbiecie Radziwiłłównie i Annie Jordanównie, przekład dzieła O żywocie i śmierci najaśniejszej księżny parmeńskiej (Kraków 1581).

Nie znamy kazania, jakie wygłoszono z okazji pogrzebu Doroty Barzinej. Cechę swoistą edycji mowy rocznicowej stanowi brak nazwiska autora oraz listu dedykacyjnego. Dowodzi to, iż inicjatywa publikacji tekstu musiała wyjść z kręgu jezuitów, nie miała zaś związku z rodziną zmarłej. Wydaje się to o tyle zrozumiałe, że Barzina znaczne kwoty przeznaczyła na wspieranie dzieł podejmowanych przez zakon oraz na prowadzone we własnym zakresie zadania charytatywne i wychowawcze. Do osiagnnięcia samodzielności przez syna Barzina sprawowała opiekę nad majątkiem. Zapewne nie mieli jej wiele do zawdzięczenia spadkobiercy Stanisława Mińskiego (córki Barbara, Dorota i Anna oraz zięciowie Marcin Zaręba i Jan Tęczyński, podczaszy królowej Konstancji) ${ }^{22}$, jak też rodzina Stanisława Barziego, stąd ich brak zainteresowania w upamiętnieniu zmarłej.

\section{STRUKTURA KAZANIA}

Myśl przewodnią kazania stanowią słowa z I Listu do Tymoteusza (3, 1): „Viduas honora, quae vere viduae sunt - Wdowy czci, które prawdziwie wdowy są”. Celem kaznodziei stało się pokazanie na przykładzie biografii Barzinej wzorca osobowego pobożnej wdowy. Makowski dowodził istnienia paraleli między czynami wojewodziny krakowskiej a życiem rzymskiej wdowy, św. Pauli²3 — kilkakrotnie powoływał się na jej przykład. Tekst św. Hieronima jest także ważny dla Makowskiego jako wzór w konstruowaniu kazania. Zwraca uwagę wprowadzenie rozbudowanej dygresji przynoszącej wykaz zacnych polskich wdów, jak też dokładniejszej charakterystyki zasług dla polskich jezuitów Zofii ze Sprowa Odrowazzówny $1^{\circ}$ voto Tarnowskiej, $2^{\circ}$ voto Kostczyny, matki Anny Alojzji Ostrogskiej i Katarzyny Sieniawskiej, fundatorki kolegium w Jarosławiu. W liczącym 44 strony druku (samo kazanie liczy 42 strony) dygresja zajęła autorowi osiem stron (16-23). Zatem niejako „przy okazji” upamiętnienia Barzinej postanowił Makowski uczcić także inne dobrodziejki zakonu jezuitów. Jest to tym bardziej widoczne, że Zofia Kostczyna nie spełniała do końca kryteriów wdowieństwa, ponieważ po dwunastoletnim okresie bezżeństwa wyszła ponownie za mąż, urodziła dwie córki i zmarła w stanie małżeńskim. Kaznodzieja zdawał sobie sprawę z częściowej tylko przystawalności biografii tej postaci do sytuacji, ponieważ stwierdził: „Lecz szerzej podobno niż miejsce i czas niesie o niej mówię i boję się, by mi kto za złe nie miał, iż o wdowach postanowiwszy, tę wspominam, którą mąż pogrzebł”24. Wprowa-

\footnotetext{
${ }^{22}$ Zob. S. Gruszecki, Miński Stanisław, s. 320-322.

${ }^{23}$ Jej żywot zob. w: P. Skarga, Żywoty świętych starego i nowego zakonu, t. 1, Petersburg 1862 (reprint Warszawa 1996), s. 138-142.

${ }^{24}$ A. Makowski, Roczna i wieczna pamiątka, s. 22.
} 
dził ją jednak, ponieważ jego celem było nie tylko uczczenie wdów, ale także szerzej, dobrodziejek zakonu.

W kazaniu żywa jest również pamięć współpracy Piotra Skargi z laikatem. To kaznodzieja królewski był obecny przy śmierci Jana Krzysztofa Tarnowskiego w roku $1567^{25}$ oraz, jak wspomniano, ofiarował Barzinej Modlitwy nazwane Gospodarstwo duchowne w roku 1606, gdzie w liście dedykacyjnym wspominał o zasługach Zofii Mnichowskiej, Małgorzaty Kozłowskiej i Anny Komarnickiej dla krakowskiej placówki jezuitów. Obszerny cytat z przedmowy do Gospodarstwa duchownego (s. 23-24) stanowi kontynuację laudacji ku czci wdów. Natomiast przywołanie słów Jakuba Wujka z przedmowy do „Ksiąg żywota P. Jezusowego” (s. 11), cytatów z wypowiedzi Piotra Skargi na jej temat $($ s. $25 ; 38)$ oraz świadectwa Marcina Laterny, jej spowiednika (s. 33), to dowód sięgania po wsparcie największych autorytetów, pierwszoplanowych animatorów i ideologów katolicyzmu potrydenckiego w Polsce w celu podniesienia rangi nie tylko postaci, ale także wizerunku, mającego pełnić funkcję wzorca.

Struktura kazania jest zgodna z obowiązującymi w początku XVII wieku konwencjami oratorskimi. Mamy więc prooemium z propositio w postaci motta, narratio $\mathrm{z}$ genealogią i biografią zmarłej, argumentatio służące przedstawieniu czynów Barzinej, dowodzących zaawansowanego rozwoju duchowego, jak też conclusio zasygnalizowane zapisem „Zamknienie” (s. 42). Formę dygresji, po rozbudowanej charakterystyce zasłużonych wdów, już nieco mniejszą rozmiarami, przybrała biografia syna Barzinej, Stanisława Mińskiego (s. 12-14). Makowski uwypuklił jego pobożność i zasługi wstaraniach o kanonizację św. Jacka. Prezentacja dokonań Mińskiego pokrywa się z częścią przedstawiającą życie Barzinej w stanie małżeńskim.

Samą charakterystykę postaci i czynów Doroty Goryńskiej podzielił mówca na kilka etapów. Pierwszy z nich, przedstawiający pochodzenie, wygląd zewnętrzny, heroiczną postawę $\mathrm{w}$ dzieciństwie, szlachetne obyczaje $\mathrm{w}$ stanie panieńskim, otwiera rozbudowane narratio. Drugi etap to pozbawiona szczegółów i niewiele o niej mówiąca charakterystyka okresu małżeńskiego. Etap trzeci stawia w centrum uwagi życie w stanie wdowim. Prezentację tę podzielił mówca na dwie części. Pierwsza znalazła się jeszcze w narratio, przyjąwszy formę opisu zmian w organizacji egzystencji, służących wdrożeniu praktyk pobożnych, które Barzina uznała za odpowiadające stanowi wdowiemu. Druga część to już argumentatio nawiązująca do typowej dla struktury kazania pogrzebowego konwencji pożegnania osoby zmarłej. Mówca przedstawił obszary aktywności wdowy z podziałem na sfery niebiańską (Bóg, święci), podziemną (dusze cierpiące w czyśćcu) i ziemską (misje społeczna i charytatywna). W conclusio skierował napomnienie do słuchaczy, zachęcając do porzucenia wzorem Barzinej życia, które nie służy osiągnięciu zbawienia.

KONWENCJE KAZNODZIEJSTWA POGRZEBOWEGO A FUNKCJE TEKSTU HAGIOGRAFICZNEGO

Makowski starał się w oracji ku czci Barzinej osiagnąć jednocześnie dwa cele, które zwykle realizowano z pomocą odmiennych konwencji literackich. Chciał wygłosić

\footnotetext{
${ }^{25}$ Tamże, s. 17. Zob. też W. Dworzaczek, Hetman Jan Tarnowski, Warszawa 1985, s. 324-325.
} 
kazanie rocznicowe (ono było strukturą nadrzędna) i zarazem stworzyć trwalszy żywot osoby świątobliwej (sięgnął po elementy struktury właściwej hagiografii). Próba jednoczesnej realizacji tych celów wymuszała wyjaśnianie podejmowanych decyzji. Mówca wywiązał się z tego w uwagach metatekstowych.

Zarazem zamiar uczynienia z kazania rocznicowego tekstu o walorach hagiograficznych utrwalony został w tytule kazania: „Roczna i wieczna pamiątka”. Makowski następująco uzasadniał, dlaczego konieczne jest upamiętnienie osoby i czynów zmarłej wykraczające poza czas wyznaczany przez konwencje kaznodziejstwa rocznicowego:

[...] Roczną mówię, jeśli roczną zwać się godzi względem jej zacnej osoby, która nie tylko tego jest godna, żeby w świeżej i w ustawicznej pamięci naszej była, ale też to sobie cnotliwym zachowaniem i wiątobliwością żywota prawie dobrze u wszystkich wysłużyła. (s. 3)

We wstępie tłumaczył autor także, w nawiązaniu do tytułu kazania, dlaczego jest ono mimo wpisanych w nie celów żywotopisarskich, nadal roczną pamiątką:

Acz że my roczną zowiemy, niech się nikt nie obrusza, bo to czynimy trybem zwyczajnym, oglądając się na on czas żałosny, którego się z nami rozstała i ostatnie, jako na żegnaniu bywa, rękę dała. (s. 3)

Makowski postanowił też przedstawić „zacne urodzenie jej Mości”, mimo że wydawać by się mogło, iż jest to sprzeczne z konwencjami hagiograficznymi, a bliższe kaznodziejstwu pogrzebowemu. Autor zdawał sobie sprawę z odmienności konwencji obu gatunków, gdyż starając się je pogodzić, powołał się na autorytet innych hagiografów:

Pocznę tedy ode krwie i zacnego urodzenia; godzi się to wspomnieć i na pogrzebach zwyczaj niesie. Historyje żywotów śś. nigdy tego przymiotu ku czemuś lepszemu nie zamilczą. Św. Hieronim wysławia śwwiętą) Paulę wdowę, iż wyszła z przodków zacnych [...]. (s. 7)

Jeden z celów kazania rocznicowego stanowi pochwała zmarłego (laudatio personae). Podobnie hagiografia dąży do przedstawienia czynów osób uważanych za święte. Zbieżność celów obu form pozwoliła Makowskiemu w oracji połączyć cechy typowej pochwały zmarłego z konstrukcją wizerunku osoby świętobliwej.

Nie każdy wizerunek kreślony w kazaniu pogrzebowym ma na celu dowodzenie świętości. Najczęściej mówcy, opisując czyny i chwaląc zmarłego, kreują wzór osobowy, który dają do naśladowania słuchaczom, zwłaszcza potomkom zmarłego. W przypadku Barziny jej postawę również podaje się do naśladowania, ale nie zstępnym, lecz szczególnej grupie odbiorców, kobietom żyjącym w stanie wdowim. Realizując ten cel autor nie nakreślił pełnej biografii osoby. Skoncentrował się na okresie, gdy była już wdową. Budowany wizerunek wykracza poza konwencje właściwe laudatio personae kazania pogrzebowego. Argumenty zostały dobrane i pokazane w taki sposób, by dowodziły świętości zmarłej.

Formułując tezę kazania Makowski zapowiedział, iż kreśląc wzór osobowy, będzie przedstawiał dokonania nierozpoznawalne według skali wartości doczesnych, natomiast bezcenne w perspektywie wieczności. Wychwalał jej postawę wobec wszystkich, „[...] którzy w niebie, w czyśćcu i na ziemi” (s. 4), wyrażając nadzieję, iż otrzymała 
stosowną nagrodę. Natomiast kazanie miało przybliżyć słuchaczom i czytelnikom jej postać i postawę oraz ukazać powody, dla których zasługiwała na miano świątobliwej:

Lecz jeśliby jeszcze komu była osoba jej nieznajoma i zasługi snadź nie tak dalece wiadome, powiem i co zacz była, i jako tego godna, aby za tych wszytkich, którzy w niebie, w czyśćcu i na ziemi są, głosem jednostajnym w wiecznej chwale zapłatę swą wzięła. (s. 4)

Celem perswazji laudacyjnej stało się więc przekonanie odbiorcy, by śledząc poczynania Doroty Barzi uznał ją za osobę świętobliwą, a jej czyny i postawę za godne naśladowania.

\section{Elementy hagiograficZnego Wizerunku Doroty Barziny}

Biografię Doroty Barzi przedstawia się następująco: pochodzenie, stan małżeński (właściwie pochwała czynów syna), pobożne czyny, znoszenie prześladowania, praca na rzecz Kościoła, umartwienie (posty, włosiennica), okazywanie pokory, troska o jezuitów (datki), ubogich (jałmużna), chorych i uwięzionych (opieka), założenie szkoły dla panien, pobożna śmierć.

Nie ma więc cudów towarzyszących narodzinom, cudów za życia, przy agonii, ani pośmiertnych. Makowski skoncentrował się na ostatnim okresie życia Doroty Barzi. Dokonał służącego perswazji tendencyjnego wyboru. Tej dominancie podporządkował zarazem pozostałe, także wcześniejsze etapy.

Chcąc rozpocząć charakteryzowanie zmarłej, odwołał się mówca do wspólnego doświadczenia własnego i słuchaczy. Przypomniał długie lata służby Barzinej w kościele św. Barbary. Pozornie więc była wszystkim znana, lecz owa „znajomość” była powierzchowna, realizowała się w sferze ciała: „po wierzchu tylko biegały oczy nasze” (s. 6). Tymczasem konieczne było pokazanie walorów jej duszy. Pytał Makowski, jak je poznać: „izali ze krwie i z urodzenia? [...] Z ciała i z urody jego?” Negatywna odpowiedź na te pytania doprowadziła mówcę do stwierdzenia: „Duszę by poznawać, ale i tę nie skądinąd, jedno z samej dusze” (s. 7). Rozważania dowodzące marności ciała umożliwiły sformułowanie jednego z celów oracji, jaki stanowiło poznanie duszy Barzinej. Wzór doskonałego opowiadania o świętej wdowie znalazł mówca w Ewangelii św. Łukasza $(Ł k$ 4, 26). Natchniony autor skoncentrował się wyłącznie na walorach duszy postaci. Makowski nie zanegował tego typu prezentacji, obrał jednak inną drogę:

Jednak że i tę perłę chciał Bóg mieć jako w skorupie zawartą w śmiertelnym ciele, od tej skorupy począć i tę skruszyć wprzód przyjdzie, aby puszkę otworzywszy, piżmo cnót czuć się lepiej dało i jasność dusze jej wolniejszym promieniem słowa moje abo raczej samę siebie oświeciła. (s. 7)

Dostrzegł tym samym trudność w oddzieleniu spraw duszy i ciała ludzkiego. To przekonanie nie wynikało ze względów doktrynalnych lub filozoficznych. Dyktowała je konieczność rozpoczęcia rozważań od prezentacji pochodzenia Doroty Barzi, zgodnie ze zwyczajem przyjętym w kaznodziejstwie pogrzebowym, ale również w piśmiennictwie hagiograficznym. Mówca zarazem sygnalizował kruchość owej „skorupy cielesnej”. 
Prezentując pochodzenie Barzi z domu Goryńskiej, odwołał się do genealogii św. Pauli, która również legitymowała się wysokim urodzeniem. Makowski dowodził, że szlachetność rodu nie stanowi przeszkody w drodze do świętości. Odwołał się do symboliki herbowej Sobockich i Goryńskich, zwracając uwagę na jedną różę w znaku ojca i trzy róże w znaku matki. Przekonanie o szlachetności kwiatu, wyliczanie jego przymiotów służyło konstruowaniu analogii do cnót członków rodu:

Kwiat ten miedzy kwieciem innym przodkuje i dom ten miedzy familijami nie pośledz idzie. Jako róża w gęstwinie a w jasne rozłożona liście, tak i ta familija w takie się składa ludzie. Wonność tej róży, sława jest domu tego i też dzielności cnót synów jego. $Z$ różej posiłek i lekarstwo, więc i ozdoba, a Rzeczypospolitej z tej familijej pomoc, okrasa i zdrowa rada. (s. 8)

Makowski tworząc analogię, dowodził szlachetności rodów obojga rodziców, by pokazać, iż przymioty Doroty Barzinej to także dziedzictwo po przodkach. Przedstawiając domy rodziców, zrezygnował z bliższej charakterystyki ojca Doroty i jego rodu, by więcej uwagi poświęcić matce i rodzinie Sobockich.

Następująco uzasadniał Makowski swoją decyzję:

Nie chcę o ojcu i po ojcu więcej i że czas sobie na co inszego chowam i że na tę osobę pomnię, która mię tu wprowadziła. Goryńskiemu gdybych dziś służył, z zacności ojca jego materyją czerpać by mi przyszło; lecz że cna córka jego, język mój zamówiła, niech go matka swą liniją prostuje i słów na jej sławę dodaje (s. 8).

Słowa te to zarazem następna uwaga metatekstowa ujawniająca motywy, jakimi kierował się kaznodzieja, konstruując mowę rocznicową. Świadomie wprowadzając do wypowiedzi jedne wątki, z innych rezygnował. Przedstawiwszy genealogię Doroty po kądzieli, sformułował mówca kolejne pytanie także w postaci uwagi metatekstowej: „Ale na cóż się ta przygodzi praca?” (s. 10). Odpowiadał na nie Makowski w ślad za św. Hieronimem charakteryzującym św. Paulę oraz uzasadniał wprowadzenie części argumentów przekonując, , „...] że trudno tym pogardzič” (s. 10). W istocie chodziło o wydobycie kontrastu między dążeniem do sławy doczesnej, co charakteryzować miało przodków (symbolem chwilowość piękna kwiatu róży), a sięganiem po dobra wieczne, co wybrała Dorota (symbolem „rosa mystica”). Celem tego zabiegu było dowiedzenie bardzo wczesnego wyboru drogi świętości przez Goryńską, co uprzytamniał Makowski w marginalium: „Pierwsze powołanie na służbę bożą” (s. 10). Dowodem miało być branie przez pięcioletnią dziewczynkę winy za siostry, które psociły w domu. Mówca interpretował postawę małej Doroty jako przejaw pokory, cierpliwości i umiejętność cierpienia za innych:

Acz tego świat nie zaraz przyznać jej chciał, co na on czas poznała, gdy się na pięcioletną panienkę niektóre domowe zwaśniły i co wiedzieć jako się jej nie przykrzyły, seu turbo nascenti rosae, jakich kłopotów nienaganiały, szkody wymyślnie czyniąc i siła zmyślając tylko dlatego, aby jej kłopotu nabawić. Bo czego same nawarzyły, to na nie ani chciała wymawiać, ale by przestępca, wszystkie cudze ekscesy na się cierpliwie brała. A prze wielkie a gęste owych występki, a tej cierpliwość i milczenie, przychodziło do tego, że ją za omamioną miano i wiązano, i zamykano [...]. (s. 10-11) 
Godne uwagi jest oskarżenie panny Goryńskiej o utratę zmysłów. Można je interpretować jako dowód wyboru drogi świętości, która polegać ma na odrzuceniu logiki świata. Jej miejsce zastąpiło postrzeganie spraw z perspektywy nadprzyrodzonej. Mówca proponuje zarazem, by czyny świadczące o dążeniu do świętości odczytywać, w kontekście tradycji, także jako objawy szaleństwa. Zaliczył Makowski Dorotę już u progu jej drogi życiowej w poczet szaleńców Bożych gotowych cierpieć dla racji uznawanej za wyższą.

Prezentacja szlachetnego pochodzenia zastępuje w żywocie Goryńskiej właściwe hagiografii cudowne poczęcie i narodziny. Pojawił się już jednak wątek bardzo wczesnego wyboru do służby Bogu. Nie dokonało się to w formie iluminacji, ale dawało się odczytać z postawy bohaterki gotowej od najmłodszych lat do cierpienia za innych i umartwień.

Okres młodości to zarazem czas zmagań o wybór drogi życiowej. Makowski dowodził jej przeznaczenia od dziecka do służby Bogu. W tym celu uwypuklał kontrast między pięknem cielesnym i duchowym. Nie mógł jednak odmówić urody Goryńskiej, dlatego stwierdził, iż piękne ciało jest więzieniem dla duszy. Wątek przedstawiający „obyczaje i zwierzchną układność Jej Miłości” (s. 11) poprzedził następującą uwagą:

Aczkolwiek tedy i skąd duszę jej moglibyśmy poznać, gdyż jako sentencyja, którą bryzelija pod bierze cudna jest ${ }^{26}$, tak dusza, która po krwi zacnej pływa, sama być zacna musi; jednak iż to lice nie tak ją wydaje ${ }^{27}$, jako raczej kanceluje $e^{28}$, trzeba skądinąd poznać się z nią, aby się nam im dalej, tym jaśniej widzieć dała. (s. 11)

Kaznodzieja pisał o urodzie Goryńskiej, powołując się na świadectwo służącej. Porównywał ją też do biblijnej Estery, wreszcie sięgał po autorytet Jakuba Wujka, który charakteryzował jej cnoty we wstępie do „Ksiąg żywota Pana Jezusowego”. Przybliżył urodę, posiłkując się także słowami Pieśni nad Pieśniami opisującymi Oblubienicę Boga $^{29}$. Wyjątkowa zgodność przymiotów duszy i ciała — jak dowodził mówca zjednywała jej uznanie u ludzi.

Nie mamy opisu walki Goryńskiej o zakonny habit, nie mamy świadectwa sprzeciwu wobec planów wydania jej za mąż, nie mamy informacji na temat szczegółów dwukrotnego pożycia małżeńskiego. O pierwszym mężu dowiadujemy się bardzo niewiele. Mówca nie wspomniał jego imienia, ograniczywszy się do stwierdzenia, że był „[...] Jego M‘ość P‘an〉 Miński człowiek wielki i urzędów, i tytułów nacelniejszych godny” (s. 12). Bardzo wiele uwagi poświęcił natomiast synowi, Stanisławowi Mińskiemu. Makowski pokazał go jako wiernego sługę króla i Kościoła, który zmarł w drodze, chcąc stawić się przed władcą, by podjąć kolejną misję dyplomatyczną. Kaznodzieja

\footnotetext{
${ }^{26}$ Bryzelia — pstre ozdoby. Sens: ...gdyż jak morał, który kryje się pod ozdobnymi słowami godny jest podziwu...

${ }^{27}$ Wyraża, pokazuje.

${ }^{28}$ Unieważnia.

${ }^{29}$ Motyw powrócił w końcowej części argumentatio, gdy pokazał przygotowanie do śmierci jako szykowanie się na spotkanie z oblubieńcem. Było to zarazem nawiązanie do przypowieści o panach roztropnych i nieroztropnych w formie uwagi, że Barzina miała szykować swoją lampę.
} 
wspomniał także o na pół cudownym odzyskaniu słuchu przez Mińskiego. By dopełnić pochwalnej mikro-prezentacji tej postaci, wspomniał także mówca o potomstwie syna Goryńskiej. Wprowadzenie pochwalnego portretu Mińskiego było możliwe dlatego, że zmarł 6 lat przed matką (w 1607 roku).

Makowski również drugiemu mężowi poświęcił niewiele uwagi. Wymienił sprawowane przez niego urzędy, zrezygnował z charakterystyki postaci, dowodząc że jest dobrze znana słuchaczom. Śmierć Stanisława Barziego dała Dorocie możliwości, jakie miały na przełomie XVI i XVII wieku tylko wdowy. Zyskała samodzielność, której nie wykorzystała, jak przekonywał Makowski, używając świata, ale ignorując pokusy. Przechodziła obojętnie wobec spraw doczesnych: „,...] ta od tego czasu tak się z nim [światem - przyp. M. K.] obchodziła, jakoby go jak żywo nie znała; i mieli z sobą pokój i wieczne przymierze" (s. 14).

Najdokładniej scharakteryzował Makowski życie w stanie wdowim. Postawił tezę o szczególnej wartości jej egzystencji w tym okresie dowodząc, iż „[...] w którym ta bogobojna Pani tak żyła, jakoby bez krwie i ciała anijołem była" (s. 15).

By podkreślić szczególną rangę wdowieństwa w życiu Barzinej, poprzedził Makowski prezentację jej cnót wywodem opartym na autorytecie św. Jana Chryzostoma i św. Pawła Apostoła na temat miejsca wdów w pierwotnym Kościele. Mówca informował, iż żyły one w odosobnionych wspólnotach zorganizowanych na wzór zakonnych, używały habitów, składały śluby. Warunkiem przyjęcia było ukończenie 60 roku życia oraz pozytywne przejście próby. Szczególną rangę osób należących do tego stanu podkreślać miało odnotowywanie ich zasług w „regestrach kościelnych” (s. 15). Służyło upamiętnieniu dokonań w formie zanoszonych modlitw i służby Bożej. O tym samym świadczyło wprowadzenie do wielkopiątkowej modlitwy powszechnej wezwania za wdowy. Makowski, przekonując o szczególnym znaczeniu wdów, podał liczne przykłady osób należących do tego stanu, które odegrały istotną rolę w dziejach biblijnych i historii Kościoła, od prorokini Anny aż po liczne dobrodziejki jezuitów w Rzeczypospolitej. To rozbudowane amplifikacyjne wprowadzenie służyło nadaniu szczególnej wagi charakteryzowanym dalej postawie i czynom Doroty Barzi. Makowski przekonywał o sakralnej wartości jej życia i podejmowanych dzieł.

Opis zasług otwierają uwagi na temat szczególnej roli domu Barzinej, do którego przybywały wdowy i panny. Poszukiwanie opieki u wojewodziny krakowskiej przedstawił mówca, odwołując się do symboliki orła: „Do tej jak orłowie do ciała, one się wielkie wyższej pomienione wdowy garnęly i z Polski, i z Węgier, z odległych miejsc zjeżdżały” (s. 25). Samą wdowę porównał do królowej Saby szukającej kontaktu z Salomonem dla jego mądrości. Ową mądrością dla Barzinej był Chrystus. Garnące się pod jej opiekę wdowy podążały ku domowi wojewodziny jak pszczoły do ula. Odwołania do toposów orła i pszczół służą laudacyjnej amplifikacji cnót postaci. Jej dom to, według Makowskiego, „Seminarium sług Bożych” (s. 25). Opieki Barzinej miały pragnąć także panny, które przygotowywała do życia konsekrowanego.

Dalszą część argumentatio poprzedził Makowski znamiennymi zapowiedziami: „[...] obaczmy raczej i uważmy jako się też i sama w swym stanie wdowim zachowała 
i co ku naśladowaniu wdowom zostawiła” oraz w glosie marginalnej: „Obraz wdowiej zakonności” (s. 26). Stanowiący wzorzec osobowy wizerunek wdowy chrześcijańskiej został podzielony na dwie części. Pierwsza (należąca do argumentatio) przynosiła charakterystykę profilu odmienionego życia, w którym najważniejsza stała się asceza, druga część (należąca do narratio) to zapis służby i praktyk religijnych.

Plan wizerunku wyznaczył kaznodzieja, sygnalizując w marginaliach kolejno rozpatrywane elementy. W części pierwszej wyliczył: „Umartwienie zwierzchnie”, „Osobność, „Odzienie proste”, „Posty”, Włosiennica”, „Umartwienie wnętrzne. Pokora”, „Prześladowanie”; w części drugiej uwzględnił: „Modlitwy”, „Kościół”, „Sumnienie”, „Spowiedź”, Komunię”, „Nabożeństwo ku świętym”, „Kazanie”, „Umarłych”, „Miłość ojczyzny”, „Afekt macierzyński ku swoim”, „Zakon Ojców Societatis Iesu”, „Ubodzy i jałmużny".

Makowski, prezentując praktyki Barzinej mające na celu adaptację do życia w stanie wdowim, wskazywał osoby, które naśladowała. Zapewniał więc, iż sama bohaterka, konstruując swój indywidualny model egzystencji, korzystała ze wcześniejszych wzorów postępowania: „I postawiła przedsię świętych onych wdów przykłady, tak Starego, jako i Nowego Testamentu, w których jako we źwierciadle przeglądała się” (s. 26). Tym samym kaznodzieja wzmacniał autorytet Barzinej dowodząc, iż jej działania były oparte na uznanych przez Kościół modelach postawy. Zarazem przypominał szlachetne wdowy i ich praktyki ascetyczne, podpowiadając odbiorczyniom kierunki poszukiwań wzorów postaw.

Porzucenie splendorów wynikających z urodzenia pokazał Makowski sięgając ponownie do symboliki herbowej róży. Obraz zwiędłego kwiatu symbolizuje odrzucenie powierzchownych oznak szlachectwa. Porównanie jej do róży jerychońskiej ma przekonać, iż bohaterka zachowała wewnątrz przymioty duchowe kojarzone z urodzeniem i te chciała kultywować. Prowadzić miała bujne życie w wymiarze transcendentalnym, niejawnie.

Przemiana objęła więc najpierw wystrój domu i ubiór. Zrezygnowała Barzina z jasnych obić i modnych strojów na rzecz kolorów ciemnych, fasonów nieco staroświeckich. Na wygląd zewnętrzny (twarz) wpłynąć miały praktyki modlitewne, jak i posty („[...] ozdoba twarzy taka, jaki jej post i modlitwa nabawiła” (s. 27). Wiele uwagi poświęcił mówca zmianom w kulturze stołu. Pierwszym krokiem była rezygnacja ze srebrnej zastawy na rzecz naczyń glinianych. Wprowadzenie w miejsce wymyślnych potraw pokarmów prostych, post cztery razy $\mathrm{w}$ tygodniu oraz rezygnacja $\mathrm{z}$ mięsa i tłuszczów, jak też wykwintniejszych napojów. Uznanie Makowskiego budzi odmowa spożycia mięsa w Niedzielę Palmową nawet w obliczu nadchodzącej śmierci. By włączyć się w misterium krzyża Chrystusa nosiła włosiennicę, praktykowała samobiczowanie, jak też spała na desce.

Makowski dostrzegł jednak większą wartość w doświadczeniach, jakim Barzina poddawała swą duszę. Będące przejawem pokory odrzucenie splendorów szlachectwa skutkowało brakiem szacunku, postrzeganiem jej jako przedstawicielki niższego stanu. 
Barzina miała lekceważyć nieustąpienie jej miejsca w ławce, konieczność siedzenia na ziemi. Przejawiała poza pokorą umiłowanie dla sakramentu spowiedzi.

Wiele uwagi poświęcił mówca prześladowaniu, jakiego zaznała wdowa. Makowski opisał długotrwałe wywieranie na nią presji przez mężczyznę z pospólstwa, który zapragnął ją poślubić. Chciał się z nią związać już wówczas, gdy obrała drogę życia w stanie wdowim. Często szukał jej sąsiedztwa będąc w kościele, dopuścił się nawet napaści fizycznej. Gdy nie osiągnął zamierzonego celu, zaczął oczerniać kapłana, który udzielił mu kiedyś, gdy klęczał obok Barzinej, sakramentu Eucharystii. Szaleniec ów potraktował ten fakt jako zawarcie małżeństwa. Makowski podkreślił, że prześladowanie trwało kilka lat. Przekonywał także, nie wchodząc w szczegóły, iż doświadczała Barzina ciężkich pokus.

Kolejna uwaga metatekstowa służy zamknięciu niewielkiego zbioru egzemplów z życia wziętych: „Mógłbym mieć wiele inszych przykładów, lecz iż mię druga część kazania do siebie zaciąga, na tym, co się jako w pospolitości dotąd mówiło, przestańmy” (s. 29). Kaznodzieja zapowiedział ciąg dalszy wywodu mający przynieść wzór osobowy.

Jako regułę życia dla wdów podawał Makowski słowa św. Pawła. Zapewniał, iż Barzina wypełniała ją bardzo skrupulatnie, osiągając doskonałość, jakiej nie posiadła „[...] z urodzenia i urody, i z małżeństwa [...]” (s. 30). Mówca dokonywał przewartościowania, dowodząc wyższości spraw ducha nad wartościami doczesnymi. Próbował poruszyć odbiorcę przekonując, że „Więtsza to jest sprawa być taką wdową, niż wojewodziną być krakowską" (s. 30).

Chcąc przybliżyć pobożne praktyki i „przedsięwzięcia duszpasterskie” Barzinej, odwołał się Makowski do zwyczaju składania ubogim wdowom jałmużny. Wzywał słuchaczy, by przekazali ofiarę na rzecz bohaterki kazania, wyrażając wdzięczność za wszystko, co ona uczyniła żyjąc na ziemi, jak też gotowa była czynić jako pośredniczka w egzystencji po śmierci. Przypomnienie jej życia i dobrych czynów postrzegał mówca jako formę odsłużenia zasług. Nawiązując do konwencji pożegnań formułowanych przez kaznodziejów w imieniu poszczególnych grup, w jakich zmarły był aktywny, oraz osób, z którymi współpracował, wymieniał Makowski kręgi, które winny okazać wdzięczność Barzinej. Stosując konwencję pożegnania, scharakteryzował dość szczegółowo sfery aktywności zmarłej.

Wzór do naśladowania stanowiło złożenie ślubów czystości wobec ks. Kaspra Czarnkowskiego przez osobę postrzeganą w kazaniu jako szczególnie pobożna i budząca szacunek wśród mieszkańców miasta. Makowski chwalił Barziną za szczerą żałość wyrażaną po śmierci męża, znowu tworząc analogię postawy jej i św. Pauli. Jako przeciwny, godny piętnowania pokazał przykład małżonek oczekujących śmierci mężów bądź przyspieszających ich zgon, by zakosztować życia w stanie wdowim i „[...] namiętnościom snadniej dogodzič" (s. 31). Przekonywał więc mówca o szczerej miłości małżeńskiej Barziny wyrażającej się szacunkiem dla pamięci męża, chwalił za łatwość, z jaką przyszło jej skierować uczucia w stronę służby Bożej. By potwierdzić autentyczność wyboru, cytował w mowie niezależnej słowa wdowy: „W pokorze (mówiła 
tak) i w skromności małżonka póki żył czciłam, a po śmierci jego hardo, bezpiecznie i rozkosznie żyjąc lżyć bym miała? Uchowaj mię tej zmazy Boże, nie dopuszczaj słyszeć z ust ludzkich owego szpetnego z uraźliwą przymówką słowa wetuję" (s. 31-32). Zastosowanie argumentu z autorytetu służy tu wzmocnieniu perswazyjności przekazu moralizującego. Niemoralne życie ówczesnych wdów musiało budzić szczególną troskę kaznodziejów, dlatego poświęcił Makowski sprawie tak wiele uwagi.

Następujący dalej opis życia modlitewnego wprowadza kolejne przykłady ascezy (,w domu i w kościele modlitwy na gołej ziemi i na gołych kolanach odprawowała, nie siedząc, ale klęcząc i niczego się nie wspierając" [s. 32]), kontemplacji (godzinne rozmyślanie odbywała leżąc krzyżem), modlitwy godzin (także noca), modlitwy litanijnej, wspólnotowej w gronie domowników, jak też szczególnie uprzywilejowanej w kościele. Na tę ostatnią położył mówca szczególny nacisk, powołując się znowu bezpośrednio na opinię Barzinej w sprawie uczęszczania do świątyni: „Na gody nie masz niepogody” (s. 32). Zachwyt mówcy budziło noszenie wdowy przez służbę do kościoła na krześle, gdy już nie mogła dotrzeć do świątyni o własnych siłach, nawet w niepogodę. Miało to budować wiernych, być może jednak widok ten budził zwykłą sensację.

Makowski chwalił Barziną także za praktyki służące kształtowaniu sumienia, jak słuchanie kazań Marcina Laterny na temat skrupułów, spowiedź odprawianą z wielką starannością dwa razy w tygodniu lub w razie potrzeby częściej, komunię świętą również przyjmowaną co najmniej dwa razy w tygodniu dopełnioną pozostawaniem przez godzinę w milczeniu. Wspominając o Laternie, chwalił Makowski praktykę kierownictwa duchowego.

Kazanie przynosi także charakterystykę profilu religijności. Barzina czciła Najświętszą Pannę, św. Stanisława i św. Jacka, a więc świętych lokalnych. Ważny był również udział w ruchu pątniczym (pielgrzymowała do Częstochowy), praktykowane co piątek na Skałce modlitwy we włosiennicy. Kolejny rys religijności to umiłowanie Słowa Bożego wyrażające się między innymi częstym słuchaniem kazań. Już na tym etapie wywodu wspomniał Makowski o zgromadzeniu orszaku panien przez Barziną, które brały udział razem z nią w praktykach religijnych. Zdaniem mówcy ów orszak robił duże wrażenie na mieszkańcach Krakowa.

Charakterystyka praktyk pobożnych z kultem Matki Boskiej i świętych, wieloma godzinami spędzonymi zwłaszcza w kościele św. Barbary to argumenty pozwalające Makowskiemu postawić tezę, iż Barzina zaznała miłosierdzia Bożego po śmierci.

Mówca zwrócił także uwagę na opiekę, jaką otaczała dusze zmarłych. Pamiętała nawet o rocznicach śmierci osób, które dawno odeszły. Wspominała nie tylko przyjaciól, ale też sługi. Troszczyła się o ich dusze, zamawiając msze święte, wpisywała do rejestru intencji Bractwa Miłosierdzia. Makowski zapewniał, iż nad Barziną czuwała z zaświatów dusza syna. Matka zaś wstawiała się za nim u Boga, podejmując również posty. Cenił Makowski jej pamięć i troskę o los dusz zmarłych.

Wysoko szacował kaznodzieja także miłość ku ojczyźnie wyrażającą się zanoszeniem modlitw podczas niepokojów w Krakowie towarzyszących zmaganiom pod Byczyną. Zdaniem Makowskiego sukces militarny to dowód skuteczności jej żarliwych modlitw. 
Wspomniał także mówca o trosce, jaką otaczała najbliższych, szczególnie wnuczki. Posługując się słowami córki św. Pauli, Eustachii, dowodził mówca, że jako spadek zostawiła im Barzina „dziedzictwa cnót świętych i łaski Chrystusowej” (s. 38). Słowa poświęcone relacjom z najbliższą rodziną świadczą o braku zainteresowania kaznodziei tą sferą życia zmarłej albo o chłodnych stosunkach z wnukami.

Więcej uwagi poświęcił natomiast Makowski trosce Barzinej o zakon jezuitów i kościół św. Barbary. Opisując jej dokonania odwoływał się do autorytetu Piotra Skargi, który wspominał o własnoręcznym sprzątaniu świątyni przez pobożne wdowy z możnych rodów, jak też o hojnych datkach. Mówił Makowski także o trosce, jaką otaczała chorych członków zakonu, których odwiedzała i pielęgnowała, o częstym zapraszaniu jezuitów do jej domu na posiłki.

Ostatnią grupa, która winna okazać wdzięczność Barzinej i oddać jej modlitwę za otrzymane dary, byli wszyscy beneficjenci jałmużny. Do tego grona zaliczył mówca przede wszystkim domowników, zwłaszcza ubogie panny. Ponadto pozostałych ubogich, których żywiła oraz obdarowywała datkami pieniężnymi, chorych (w tym dzieci), których odwiedzała w szpitalach opiekując się nimi, nawiedzanych więźniów. Makowski wzywał wszystkie grupy, które doznały jej wsparcia, do modlitwy za duszę zmarkej lub do płaczu.

Dopełnienie hagiograficznego wizerunku stanowi opis zgonu Barzinej. Makowski przekonywał, iż była do śmierci doskonale przygotowana, ponieważ zgromadziła dobre uczynki spełnione względem tych, co w niebie, czyśćcu i na ziemi, doświadczyła cierpienia w chorobie poprzedzającej zejście, doznała wreszcie zdziecinnienia. Kaznodzieja opisał czynności bezpośrednio przygotowujące ją do śmierci: wysłuchanie mszy świętej, przyjęcie Eucharystii, częste powtarzanie wyznania wiary, zgon w obecności czterech jezuitów z krzyżem i świecą w rękach. Makowski zanotował dokładnie wiek i czas odejścia (s. 42).

Również ta relacja ma dowodzić cnotliwej heroiczności postawy i uczynków zmarłej, które przejawiać się miały w pełnej pokory, często także humanitarnej, trosce o człowieka ubogiego, zagubionego lub chorego. Barzina nie była jednak tylko działaczką społeczną. Źródło jej poczynań stanowiła zadeklarowana postawa religijna, której świadectwem praktyki ascetyczne i bogactwo form modlitwy.

Wszystkie wymieniane kolejno grupy: święci, zmarli, kaznodzieje, ojczyzna, wnuki, jezuici, domownicy, wreszcie ubodzy winni jej dziękować za pamięć, troskę i opiekę, jak też odpłacić tym samym. Charakterystyka Barzinej służyła uwypukleniu jej cnoty pozyskiwanej spełnianiem uczynków miłosierdzia wobec duszy i ciała.

W „zamknieniu” nie zajmował się Makowski osobą Barzinej. Skierował wykład moralizujący do szlachetnie urodzonych słuchaczek, wzywając je do aktywizacji postaw religijnych. Tym samym adaptował naukę płynącą z życia bohaterki kazania do potrzeb odbiorcy.

Odwołał się mówca do egzystencji osób, które szczyciły się tytułami. Wyrzucał im, że ich postawa nie wyrażała tego, co niosły z sobą symbole szlachetnego urodzenia. 
Zwracał się do pań określanych zwyczajowo w ramach obowiązującej wówczas nomenklatury jako Jaśnie Oświecone (pytał, czemu siedzą w ciemnościach), Wielmożne (pytał, czemu nie podejmują działań ku chwale Bożej) oraz Miłościwe (zarzucał im pogardę wobec ubogich). Przekonywał wszystkich słuchaczy, by w trosce o zbawienie sięgali po to, co najlepsze. Pragnienie nieba i obcowanie z Bogiem w wieczności wynikać miało z uprzywilejowanego miejsca człowieka na ziemi, stanowić jego przedłużenie.

Makowski zwracał się szczególnie do szlachcianek i magnatek. Zachęcał je do współzawodnictwa o dobre miejsce w niebie z przedstawicielkami niższych stanów, wzywał do wykorzystania potencjału, jaki otrzymały dzięki uprzywilejowanemu urodzeniu. Dowodził, iż jak złączone jest ciało z duszą a prawda z mową, tak samo spojone winno być szlachectwo z pobożnością, „zacne urodzenie ze świątobliwością” (s. 43). Porównując do drogich kamieni cnotę postrzeganą jako dar od Boga przez osoby należące do szlacheckich rodów przekonywał, iż otrzymały więcej niż przedstawicielki niższych stanów. Zarazem jednak mają trudniejsze zadanie do wykonania, ponieważ posiadając większe możliwości wyboru, winny rezygnować z konkurencyjnych propozycji świata. Owe marne rzeczy świeckie kazał mówca omijać, zachęcając do naśladowania Chrystusa. Demaskował ponadczasowe wymówki tłumaczące poniechanie żarliwości religijnej, zwłaszcza trudne czasy, ale też ujawniał praktyki polegające na samousprawiedliwianiu życia w nieprawości. Głosił wartość cnoty pozwalającej przetrwać w pamięci pokoleń osobom, które się jej poświęciły, prowadząc jak Barzina pobożne i aktywne życie. Przekonywał, że i oni mogą stać się wzorami, zapisując się dzięki cnotliwemu, pobożnemu i świętemu życiu w pamięci pokoleń. Nawiązał do tytułu oracji, podkreślając jej znaczenie jako wiecznej pamiątki. Mowę zamyka apel do Barzinej: „Żyj na świecie w nas, żyj w niebie w Bogu, i z Bogiem, nas przepominając na wieki” (s. 44).

Godne podkreślenia jest częste przywoływanie sytuacji, w których Barzina okazywała posłuszeństwo przewodnikom duchowym, jak też ich autorytatywnych świadectw na temat jej życia. W kształtowaniu postaw rolę mieli odegrać, jak wspomniano, Kasper Czarnkowski, Jakub Wujek, a zwłaszcza najczęściej przywoływany Piotr Skarga, i spowiednik Marcin Laterna. Mówca dowodził szczególnego znaczenia przewodnictwa duchowego w życiu osób pobożnych, zarazem wzmacniał autorytet kapłanów.

Makowski nie zarzuca czytelnika kazania erudycją. Autor najczęściej odwołuje się do Biblii, do miejsc, w których mowa o wdowach. Nie tak wiele poza tym innych cytatów bądź przypadków sięgania do autorytetów. Nawiązuje, budując paralelę, do żywotu św. Pauli, autorstwa św. Hieronima. Spotykamy także świadectwa św. Jana Chryzostoma, zalecenia św. Eligiusza dla Bechtyldy, kazania i listy św. Bernarda (s. 30), kazania św. Cypriana, księgę XIII Wyznań św. Augustyna, przedmowy Skargi i Wujka ofiarowane Barzinej, które obszernie cytuje.

Ujawniając kolejne role, jakie brała na siebie, pokazuje Makowski Barziną jako poszukiwaczkę mądrości na wzór królowej Saby, jako nienaganną wdowę na wzór Judyty, wdowy po Manassesie oraz na podobieństwo prorokini Anny, jako przewodniczkę dworu panien do pięknej Noemi, jako wdowę opłakującą męża na wzór św. Pauli, 
jako człowieka modlitwy na wzór św. Jadwigi oraz Bony z Saudianu (s. 32), jako matkę cierpiącą po stracie syna na wzór biblijnej wdowy, której dziecko wskrzesił prorok Eliasz, jako miłośniczkę ojczyzny na wzór Aretafili oraz biblijnej Judyty, jako opiekunkę najbliższych na wzór antycznej Erykso, zdziecinniałą porównał do nie mówiącego Mojżesza. Wpisał więc jej postawę w uniwersum wizerunków bohaterów biblijnych, a także mitologicznych. Wróciwszy do czasu, gdy żyła jeszcze w stanie panieńskim, Makowski porównuje jej ówczesną urodę do uroku biblijnej Estery.

Budując obrazowanie wyzyskuje też Makowski popularne motywy ikonograficzne, jak motywy orła i pszczoły (s. 40) oraz odradzającego się z popiołów Feniksa. Podobnie postrzegać należy nawiązanie i konsekwentne powtarzanie odwołań do herbowej róży, która przyjmuje różne funkcje aż po różę jerychońską, symbol zewnętrznej martwoty i ukrytego życia. Ciekawy wydaje się obraz pokazujący duszę ludzką w ciele podobną do cennej perły zamkniętej w skorupie.

\section{ZAKOŃCZENIE}

Godną uwagi cechą tego kazania jest wprowadzanie uwag metatekstowych, w których kaznodzieja ujawniał motywy podejmowania bądź porzucenia pewnych wątków. Jedne traktował jako obowiązkowe, inne jako fakultatywne. Świadomie konstruował wypowiedź, dobierając elementy niezbędne dla uzyskania założonego celu w postaci hagiograficznego wizerunku Doroty Barzi włączonego w strukturę kazania rocznicowego.

Mając świadomość niekompletności obrazu, stawiać należy pytania także o elementy, których brakuje w wizerunku. Przykładowo: nie wiemy, w jakich okolicznościach Dorota Goryńska została przeznaczona do stanu małżeńskiego i jak przyjęła wyswatanie jej Kasprowi Mińskiemu. Z wizerunku wynika, że od dzieciństwa myślała o przywdzianiu habitu. Mógł mówca pokazać zgodę na małżeństwo jako wyraz szczególnej pokory. Z jakichś względów nie zrobił tego. Nie wiemy także, jak reagowała jej rodzina na przeznaczanie znacznych sum z myślą o ubogich oraz inne dzieła prowadzone przez jezuitów krakowskich. Brak zainteresowania ze strony najbliższej rodziny po śmierci świadczy o negatywnym stosunku do jej sposobu dysponowania majątkiem. Mówca informował, dowodząc heroiczności cnót, iż doświadczała Barzina licznych pokus. Nie wprowadził jednak odbiorcy w szczegóły. Trudno powiedzieć czy było to podyktowane taktem i wynikało z dyskrecji, czy stanowiło świadome pominięcie z uwagi na możliwość gorszenia słuchaczy.

Wydaje się, iż autorzy współczesnych biografii Barzinej opierali się w dużej mierze na perswazyjnym wizerunku stworzonym przez Makowskiego. Jednak usuwali z niego elementy opisu informujące o jej praktykach ascetycznych i modlitewnych, natomiast koncentrowali się na dziełach społecznych (jałmużny dla ubogich, praca w szpitalu, opieka nad jezuitami starcami, szkoła duchowości dla panien i wdów) i wspieraniu zakonu poprzez pracę na rzecz kościoła św. Barbary, dostrzegali jej zaangażowanie finansowe w dzieła zakonu. 
Tymczasem Makowskiemu chodziło o stworzenie wzorca osobowego wdowy, która nie tylko podejmowałaby dzieła dla dobra społeczeństwa, ale także potrafiła poświęcić się praktykom ascetycznym, doświadczać cierpień fizycznych i psychicznych, rezygnować z przywilejów stanowych. W nakreślonym obrazie zabrakło świadectw cudów. Świadczyłyby one o wyjątkowości postaci. Ich nieobecność dowodzi jedynie szczególnego heroizmu osoby, która potrafiła realizować ideały ewangelicznych cnót na co dzień.

Mówca pokazał wizerunek Barzinej na tle innych przykładów świętości życia jej poprzedniczek. Zarazem poszczególne praktyki modlitewne, ascetyczne i wyrażające się w różnych formach posługi konfrontował ze wzorami postaw znanych z Biblii oraz z pism Ojców Kościoła. Pragnął stworzyć hagiograficzny wzór osobowy adekwatny do czasów, szczególny, ale zarazem osiągalny dla innych. O silnym związku z codziennością świadczy zakończenie wyjaśniające sens moralny zawartego w portrecie wykładu cnoty. Czy był to jednak obraz atrakcyjny? O szczególnym pragnieniu nakłonienia odbiorcy do wyboru preferowanej postawy świadczy zwłaszcza silne perswazyjnie zakończenie.

Godny uwagi jest poziom nasycenia wypowiedzi erudycją, opiniami uznawanymi za autorytarne i obrazami odwołującymi się do wyobraźni pikturalnej. Makowski rezygnował z popisów erudycyjnych, odwoływał się za to do opinii autorytetów, przytaczał nieliczne w sumie egzempla. Nawiązania do miejsc wspólnych (loci communes) wprowadzanych poprzez wyobrażenia emblematyczne, pikturalne nie są częste, ale za to ponawiane dość konsekwentnie, by utrwalić w świadomości odbiorcy: obraz perły zamkniętej w skorupie, herbowej róży przemienionej później w różę jerychońską i feniksa powstającego z popiołu.

Zauważyć trzeba także ujawnianie decyzji mówcy świadomie konstruującego orację, celowo rezygnującego z wątków typowych, z rozmysłem demonstrującego możliwości wyboru profilu i kierunku rozważań. Samoświadomość Makowskiego przekonuje o głębokiej refleksji towarzyszącej konstruowaniu wypowiedzi, przemyślanym doborze wprowadzonych argumentów, jak też celowości stworzenia tego hagiograficznego wizerunku w rocznicę śmierci Barzinej.

\section{The Hagiographic Image of the Saintly Dorothy Barzi - Creating Personal Patterns in the Adam Makowski's Sermon The Annual and Perennial Reminder}

\section{Summary}

The object of the presentation is not another attempt to reconstruct a biography, but an analysis of the image praise created by Father Adam Makowski. The image that has been created in the form of oratory. The author is respecting the rules of constructioning anniversary sermons. Convention exploits in order to make a monument for the dead, which has been created for herself, living piously fulfilling the works of mercy and materially supporting the Jesuits and the poor. The title of oration seems to indicate such an intention by the writer: The Annual and Perennial Reminder [...] Dorothy of Ojźrzaków Barzina [...] at the Memorial Service Offered. Literary imagery requires the overview in the light of hagiographic writing conventions. This is all the more necessary that Dorothy Barzi was describing as saintly, the pious, holy. 
This article presents an outline of a biographical figure, analysis of the structure of the sermon. The article juxtaposes conventions of funeral preaching and hagiographic text functions, and finally discusses the elements of the hagiographic image of Dorothy Barzi. These elements are: the origin, marital status (adequately the praise of son acts), pious activities, taking on persecution, work for the Church, mortification (posts cilice), showing humility, concern for the Jesuits (donations), the poor (charity), the sick and imprisoned (care), setting a school for girls, pious death. 